DOI: https://doi.org/10.30525/978-9934-26-020-9-6

Volodymyr Shevchenko

Candidate of Economic Sciences

National Taras Shevchenko University of Kyiv

\title{
PANDEMIC ECONOMIC IMPACT AND INTERNATIONAL RISKS
}

\section{Summary}

Unpredicted COVID-19 pandemic in 2020 has generated the worldwide shocks for countries, changed everyday life for millions of people, stressed businesses and international relations. Pandemic shocks have had strong economic impact on contractions of industries and services, continuing international economic volatility and recession. Economic shocks and their influence on the European economies are complex, foresights of recovery looks uneven. Shocks implications are causing the lasting international economic risks. The major international economic risks currently are uncertainty, recession duration and cost risk, disproportionate recovery risk, regional economic differentiation, international supply chains risks, global debt risk. Recovery prospects are dependable on risks, medical crisis mitigation and targeted economic policies implementation. 


\section{Introduction}

Epidemics and natural catastrophes are occasional in world territories. Such events are causing stresses for population, as economic shocks and crises. They are generating shocks and economic problems such as output contraction, additional governmental expenses, financial losses for business, debt increase. Post-pandemic economic shocks are generating instability, risks and crises.

The COVID-19 pandemic has caused rapid changes in the global economic and social environment, related international risks and recession.

Since beginning of the COVID-19 pandemic, the governments have introduced emergency measures in the health care and severe restrictions as isolation of people, social distancing and lockdowns in order to eliminate a spread of infection. Lockdown measures have terminated a part of businesses, services, domestic and international travel, tourism, retail trade. In result, the companies' finances have been distorted, governments' tax revenues have eroded, budget spending has seriously increased. In order to cover unforeseen expenses, the governments and corporations have borrowed financial liquidity, which increased external debts.

The pandemic influence on economy and society is transmitting by pandemic-generated shocks, which have caused contractions of output and recession. Further the pandemic-related international risks are affecting the world economy, countries and international relations. International risks are influencing the recession cost and recovery prospects.

Pandemic economic impact should be assessed with respect to interdisciplinary approach including inputs from public health, psychology, classical economics, behavioral economics, institutional economics, systemic analysis.

\section{Part 1. Pandemic shocks coherence and economic impact.}

Economic development would be affecting from time to time by events or changes which are seriously influencing the production, demand, consumption, macroeconomic situation. Such cases of unexpected influence are considering as economic shocks affecting economy and its sectors.

Economic shocks have different causes and forms, which leads to different approaches to their study in the research literature. The impact of economic shocks and their influence on different processes are among research issues. The essence of economic shocks and their impact on crises was studied by M. Lettan and S. Ludvigson [9], nature of economic shocks and their major forms have been outlined by E. Reed [13]. The economic shocks in the macroeconomic policy have been overseen by O. Blanchard [1].

The shocks could be defined as endogenous - internal shocks of the economic systems or sectors - and exogenous as shocks caused by external forces or events - natural, political, social and technological. 
Endogenous shocks can be primarily defined of economic origin. For example, changes in basic macroeconomic parameters like inflation, markets volatility or business restrictions would cause endogenous economic shocks to supply, demand, output and productivity.

External (exogenous) shocks have three main origins: 1) significant unexpected fluctuations of international commodities and financial markets, foreign capital inflows and outflows; 2) extreme natural events - floods, hurricanes, earthquakes, epidemics, droughts; 3) domestic and external conflicts - military, territorial, political, international.

The sudden and rapid spread of the COVID-19 has caused external shocks to national and global economies and societies. Pandemic has a widespread influence on the economy [10], generated shocks make impact on business, causing the economic and financial instability as overseen by A. Kose and N. Sugavara [11].

The rapid spread of the dangerous COVID-19 has caused a shock to health systems, an extraordinary demand for medical services, a lack of necessary hospitals capacities and medical supplies. Such extreme needs have raised quickly a large international demand for critical medical supplies - face masks, protection for medical personnel, special equipment, such as systems for lungs ventilation. Urgent demand for specialized infection treatment hospital facilities pursued a quick construction of new hospitals, reconstruction of large public and private spaces such as sports and exhibition halls to be converted for medical services. The shocks to the public health have caused an extraordinary demand for additional funding. Countries have attracted funding from domestic and international sources, including emergency funding from the IMF and other international organizations.

The specific of current pandemic is that it has generated initial response on virus information as psychological shock - individual and group reaction on unexpected and stressful health threats, lockdowns, business closures, restrictions. This causing the emotional reactions, threats, public protests, fears, speculations, stress-led decisions.

Many countries have implemented different measures aimed on prevention of COVID-19 spread:

- lockdown for population and businesses;

- social distancing, face masks in public places, limits for people gathering;

- restrictions for shops and shopping malls, restaurants, hotels and other services;

- relocation of employees to distance work;

- shift to electronic retail trade and cashless payments;

- shift to distance education in schools and universities, kindergartens closure;

- restrictions for transportation in the cities, domestic and international transportation;

- border restrictions. 
Such measures have generated in fact «man-made» or «governmentimposed» irregularities, which would be considered as external economic shocks. Therefore pandemic has generated a coherence of shocks with contradictory impacts on the economic and social life:

- psychological shock as serious and widespread stress for population;

- medical shock in public health due to the danger of large-scale infection, limited hospitals capacities, shortage of medicine and equipment;

- economic shocks caused by lockdowns, restrictions for businesses and international communications;

- financial shocks due to a need to cover extraordinary expenses for mitigating medical, economic and social consequences of pandemic;

- social shocks due to unemployment, shift to distance work and education.

Pandemic demand shocks are resulting of governmental lockdowns and restrictions. Business closures and households income loss are generating pandemic demand shock for energy, materials, business services. Reduced demand has caused prices decline, especially for oil and natural gas, which influencing negatively on revenues and profits in energy sector. This in turn affects production prospects, depressed investments and has spillover effect of related industries such as equipment production, construction and transportation. Partial loss of households incomes led to consumers demand stagnation.

Reduction of electricity consumption is demand shock impact caused by the lockdowns, closing of businesses and schools, restrictions for railway transport, etc. For example, in the EU electricity consumption in April 2020, was declined for $-11.2 \%$ lower than the lowest level in the same month during preceding 5 years. There were some regional differences - lowest levels were observed in the most hit by pandemic countries such as: France $15.0 \%$, Spain - 14.6\%, Luxemburg $-13.7 \%$. Seven countries showed more then $10 \%$ decrease, four countries - between 5 and 10\% less [5]. Power generation sector technologically is dependable on balance of production and consumption of electricity, therefore demand shock created some challenges for countries' power generating systems.

Pandemic demand shocks impact led to downturn in production of different goods and services, disruptions in international supply chains and international transportation. Demand for international air transport fell by $54 \%$ in the second quarter of 2020, totally 7.5 million flights have been cancelled during half a year; airlines have got 84.8 billion USD losses and have lost 419 billion USD revenues which accounts 50\% downturn [9].

Small businesses stagnation is structural pandemic impact. Demand shock seriously affected services which are traditionally run by small and medium sized enterprise. Small businesses downturns in many cases have led to shutdowns due to lack of financial reserves and limited opportunities for borrowing on the markets. Therefore SME's future in post-pandemic times looks problematic. 
Pandemic-generated supply shock became evident as downsizing of commodities and goods availability, instability of supply channels. Lockdowns led to downturn of wholesale trade due to depressed demand for energy, commodities and non-essential imports. International and domestic supply chains have been disrupted and in many cases simplified in order to avoid complexities and delivery risks. Supply stability have supersede cost saving as a criteria for supply chains performance. This is also supporting with a trend of reshoring of corporate production facilities back to home countries. Supply shocks have led to structural changes in retail trade such as rapid development of electronic trade and e-commerce especially in food supply. Various networks of food delivery have boomed during lockdowns and such trend would look competitive in the future.

Pandemic financial shocks are appearing as an urgent need to cover additional expenses for health care systems operations and supplies, relief for employees, businesses and households, lost revenues of most affected companies and sectors. Tax concessions and debt increase are major financial implications of pandemic shocks.

In order to manage response to financial shocks countries use monetary and fiscal measures. Typical monetary instruments are downgrading the central bank's rates to support commercial banks lending, quantitative easing of the money supply, emergency guarantees and loans to support bank's stability.

Urgent financial support has been provided by international institutions such as International Monetary Fund, the World Bank Group, the European Central Bank. One of the consequences of pandemic financial shocks would be further accumulation of domestic and foreign debt, increase of debt servicing cost.

Pandemic social shock have emerged along with economic shocks, businesses freezing, lockdowns, transport restrictions and appeared as full or partial loss of jobs, shift from traditional to distance work. Social shocks have progressed in second quarter of 2020 and reflecting regional differentiation. Work hours losses (part-time employment, formal employment but no work, unemployment) in the second quarter of 2020 have been estimated as: world 14.0\%, Americas - 18.3\%, Europe and Central Asia - 13.5\% [7]. Within European region differentiation is reflecting a level of the economies, labor markets specifics and governments relief measures. Work hours losses have been estimated in: Southern Europe - 18.0\%, Northern Europe - 15\%. Western Europe -14.3\%, Central Asia -13.6\%, Eastern Europe - 11.6\% [8]. The last data also reflects an existence of shadow and contract work in the region, not considered as formal employment and more flexible.

A disproportional contraction is a cross-sector impact of the pandemic shocks transmission. The economic sectors could be differentiated depending on extent of downturn due to demand, production and structural conditions. 
1) Less affected sectors are those with no or minimum loss of output due to specific of production and demand: agriculture, continuing manufacturing industries (steel, chemical. food production), municipal services.

2) Moderate affected economic sectors with output drop ranged in 10-20\% caused by demand and supply shocks: retail sales, administrative services, education, energy, car and machinery manufacturing.

3) Substantially affected sectors: tourist industry, international transportation, airlines, leisure services.

Small and medium enterprises have been seriously affected with business decrease, financial distress and bankruptcies, their depression are other major impact of pandemic namely due to their role in services, small companies also are usually less financially stable and more reliable to market changes.

\section{Part 2. Pandemic-related international economic risks.}

Shocks are transmitting pandemic impact to the economy. Following that further they are causing risks for the current and forthcoming economic processes - domestic and international. Risks are considering as probable and forthcoming deviations due to macroeconomic changes and other factors which would affect business and firms future performance resulting in loosing economic benefits.

Pandemic is global phenomenon therefore related risks spillover crossborder and act as international, which are affecting several or most of countries, cross-countries economic and financial relations.

The major international economic risks currently are uncertainty, recovery duration and cost risk, unproportional recovery risk, regional economic differentiation, international supply chains risks, global debt risk.

Complexity and global spillover of pandemic impact are affecting a longlasting changes and variations of economic processes. Uncertainty risk could be seen as unknown time frame of probable or random economic processes. It means that economic expectations and forecast are associated with unjustified probability of occurrence or reverse movements.

Risk of economic uncertainty means that rates and time of post-pandemic recovery are dependable on pandemic waves. It means that recovery might become possible when medical crises would be settled as result of wide vaccination of population in majority of countries and regions.

The economic recession in 2020 becomes a major outcome of pandemic economic shocks. Their impacts are driving the differentiation of business contraction in sectors which could be considered as one of the major international economic risks with effect on unbalanced recovery risk. The economic sectors of the European countries could be differentiated depending on extent of downturn due to demand and structural conditions.

- Less affected sectors.

- Moderate affected economic sectors with output drop ranged in 10-20 \%.

- Severely affected sectors in services. 
Disproportionate recovery risk arising from differentiated contraction, structural features of national economies, their internationalization degree, financial stance, governmental policies.

Economic recession in the European countries has a high degree of uncertainty, which is causing by pandemic situation and complexity of economic shocks outcomes. Dangerous nature of COVID-19, fears of possible second wave of pandemic and absence of vaccines make uncertain future post-pandemic recovery. Therefore, the economic prospects of many countries and the world economy are looking unstable in the short and medium term. The prospects of countries are depending on recession downturn and recovery different rates in Europe and emerging economies. The latest IMF estimates are giving a comparison of the pandemic impact for the world, developing and European countries.

Table 1

GDP development in 2019 and the forecast for 2020,\% year on year (based on the IMF World Economic Outlook updates in June 2020 and IMF World Economic Outlook October 2020)

\begin{tabular}{|l|c|c|c|}
\hline & $\mathbf{2 0 1 9}$ & $\begin{array}{c}\mathbf{2 0 2 0} \text { Forecast } \\
\mathbf{( 0 6 . 2 0 2 0 )}\end{array}$ & $\begin{array}{c}\mathbf{2 0 2 0} \text { Forecast } \\
\mathbf{( 1 0 . 2 0 2 0 )}\end{array}$ \\
\hline World & 2.4 & -4.9 & -4.4 \\
\hline Developed economies & 1.7 & -8.0 & -5.8 \\
\hline USA & 2.3 & -8.0 & -4.3 \\
\hline Euro Area & 1.2 & -10.2 & -8.3 \\
\hline Emerging and developing economies & 3.7 & -3.0 & -8.3 \\
\hline Emerging Europe & 2.1 & -5.8 & -4.6 \\
\hline Ukraine & 3.2 & -7.7 & -7.2 \\
\hline
\end{tabular}

Source: compiled by the author based on IMF data [14; 15]

The IMF world economic forecasts dated in four months period are reflecting different implications of pandemic shocks. Forecast dated June 2020 has been affected by the initial strong shocks and respective negative expectations. Forecast dated October 2020 has reflected the summer positive trends after lockdowns lifting, partial business and communication restoration.

Greater GDP contraction is expecting in Euro Area and developed economies due to intensive pandemic spread and uneven recovery prospects. Moderate contraction is expecting in emerging and developing economies despite a mixed pandemic situation. Moderate expectations for 2021 would reflect an effect of a «low base» of the 2020 downturn, while the real achievement of pre-pandemic economic indicators would be expecting in 2-3 years. Projections for Ukraine should be considering the depressed domestic demand, instability of exports and the impact of external debt servicing. 
Differences in summer and fall IMF forecasts are reflecting of pandemic stages and respective modifying of expectations. The summer forecast reflected impact of initial pandemic shocks and great degree of uncertainty. October forecast otherwise reflecting some positive changes due to lockdown termination and lesser uncertainty. Some more positive expectations in October 2020 are seen as result of lockdowns lifting in summer 2020. But second pandemic wave in the fall and further lockdowns are driving some negative trends in major European countries such as lockdowns, closure of services, retail trade limitations and travel restrictions.

It raises the risk of change from $\mathrm{V}$-shape recession to $\mathrm{W}$-shape recovery with economy ups and downs. The noted change means that each coming wave of infection may enforce the economy downturn. Certainly, it would increase recession economic cost and raise a risk for prolonged restoration.

Such unstable recovery would cause a period of low rates of the world economic growth. At the same time the progressing digitalization and fourth industrial revolution may lead to structural changes in employment and need for better quality of life, equality and social inclusion.

Another international risk is differentiating economic growth in major regions and countries. Asian countries are less affected by pandemic, now have low cases and turning to positive growth rates. In Europe, emerging Central and Eastern European countries are showing less contraction and therefore have relatively better positions for recovery.

Different contractions and recovery forecasts are affecting world trade and competition, recessions usually are associating with international trade decline, risks of disruptions and more protectionism. It raises an international trade risks as well as uncertainty and structural changes of the world trade, international competition risks.

There is a certain risk of deglobalization, increasing regionalization with Brexit and new Asian free trade agreement. Global supply chains are restructuring with more focus on the regional networks.

Risk of restrictions and disruptions of cross-countries movement of people is affecting international tourism, labor and intellectual mobility. Therefore a demand for migrant workers in some countries could not be satisfied and such situation has negative impact on economic recovery. Online activities and communication makes changes in business and consumers preferences, demand for international travel.

The economic consequences of pandemic economic shocks are differentiated in European countries due to domestic and international factors such as COVID-19 cases intensity, border and transport restrictions, conditions of international trade, volatility of international financial markets. Country-specific factors are mostly dependable on economic structures, especially shares of most pandemic-affected sectors like trade, services, tourism as well as fiscal and financial stability. 
GDP change in selected EU countries, estimate changes in 2020 and 2021 forecast, \%

\begin{tabular}{|l|c|c|c|}
\hline \multicolumn{1}{|c|}{ Country } & $\begin{array}{c}\text { GDP 2020 } \\
\text { Summer 2020 } \\
\text { estimate }\end{array}$ & $\begin{array}{c}\text { GDP 2020 } \\
\text { Autumn 2020 } \\
\text { estimate }\end{array}$ & 2021 forecast \\
\hline EU 27 & -8.3 & -7.4 & 5.8 \\
\hline Euro area & -8.7 & -7.8 & 6.7 \\
\hline Belgium & -8.8 & -8.4 & 6.5 \\
\hline Germany & -6.3 & -5.6 & 5.3 \\
\hline France & -10.6 & -9.4 & 7.6 \\
\hline Italy & -11.2 & -9.9 & 6.1 \\
\hline Netherlands & -6.8 & -5.3 & 4.6 \\
\hline Spain & -10.9 & -12.4 & 7.1 \\
\hline Sweden & +5.3 & -3.4 & 3.1 \\
\hline Estonia & -2.7 & -4.4 & 6.2 \\
\hline Hungary & -7.0 & -6.4 & 6.0 \\
\hline Poland & -4.6 & -4.3 & 4.3 \\
\hline Latvia & -7.0 & -5.6 & 6.4 \\
\hline Lithuania & -7.1 & -2.2 & 6.7 \\
\hline
\end{tabular}

Source: compiled by using EU forecast data [3; 4]

The EU economic estimates comparison for summer and autumn 2020 are reflecting slight improving of response to pandemic shocks and lockdowns. Autumn forecast has some relative improvements for the most of the EU countries.

Industrially developed countries, which are most seriously affected by the COVID-19 pandemic (especially Italy, Spain, France, Sweden), are having a relatively higher GDP contraction compared to the EU. Countries of Central and Eastern Europe (Hungary, Poland, Latvia, Lithuania) have a lower cases and lesser services sector share, their GDP downturn looks moderate.

Their complex nature and continuing pandemic are the major reasons of uncertainty of national and global economies. Different rates of GDP contraction during a pandemic will affect the chances of recovery. The uncertainty of the recovery would be influenced by the shocks impact on the national and international economies. The uncertainty of the recession and the recovery depends on a number of circumstances:

1) probability and intensity of the next waves of the pandemic and the possible scale in individual countries and regions;

2) time of production and application of vaccine against COVID-19, its effectiveness and scale of vaccination;

3) changes in business expectations and consumer behavior in the time of recession and recovery. 
To summarize the coherence of specific pandemic-related international economic risks would influence the prospects of the medical situation and economic recovery.

The major international economic risks to be considered are:

- pandemic economic impact cross-border spillover risks;

- post-pandemic recession risks;

- post-pandemic economic uncertainty risks;

- countries and regions economic differentiation and unproportional recovery risks;

- change from V-shape to W-shape recovery risks;

- international supply chains disruptions risks;

- international mobility risks;

- deglobalization, regionalism and protectionism risks.

Pandemic related international economic risks should be considered as certain coherence with individual risks variables. Their common ground is COVID-19 spread, medical system response and capacity, cost of prevention and mitigating. Therefore pandemic related risks specifics should be considered both in qualitative and quantitative aspects as well as estimated probability of occurrence. Overall macroeconomic risks - fiscal, financial, exchange rates, investment, inflation, unemployment and social - also should be simultaneously analyzing.

International risks are affecting all countries, but smaller and unstable economies could be more reliable to risks. Ukraine, as a small open economy is experiencing pandemic shocks like other European countries and applies similar policies: face masks, social distancing, restriction of public gathering, freezing of business activities, remote employment, online trade. The macroeconomic situation looks stable when inflation is still below the planned level of 5\%. In the first half of 2020 the economic performance have seriously downturned (year-to-year): industry output - $12.2 \%$, agriculture $4.0 \%$ transport $-26 \%$, electricity $-8.2 \%$ [12]. The impact of economic shocks and international risks will be cleared during vaccination results and recovery of the national economy since 2021.

Simultaneous shocks led to falling prices for oil and natural gas. Reduced demand for imported goods contributing to balancing foreign trade and balance of payments in Ukraine, support relative stability of exchange rate. The outflow of capital is mainly due to the redemption of government bonds.

\section{Conclusions}

Global pandemic shocks have appeared in several forms: psychological shocks, medical, economic, financial, social. They have affected economic and social stress, depression and public reaction.

Pandemic shocks have caused differentiated contraction in European countries due to the cases intensity and different structures of economies. This also would influence on the post-pandemic recovery specifics. 
Economic shocks have depressed demand on products and services due to lockdowns and cross-border restrictions. Service sector becomes most affected, largest airlines, travel agencies and hotel chains moved close to insolvency and apply for governmental subsidies. Downsized demand for energy has affected oil, natural gas and electricity prices.

Respectively supply shocks have disorganizes the international supply chains and have impact on the world trade.

Financial shocks have created so-called «pandemic debt» to cover extreme public health needs, economic and social relief spending.

The second wave of pandemic at the autumn has enforced uncertainty regarding future post-recession recoveries, prospects for returning to normal business and social life.

Recovery policies should be based on time-fashioned targets and instruments.

Short-term policies should be aimed at restoring business and consumption. Medium-term policy should be focused on macroeconomic stability, external balances and sustainable growth.

To strengthen preparedness for future shocks and risks, it would be needed to focus on the innovative development, advanced technologies, big data and artificial intelligence, communication networks and an inclusive social development.

Specific shocks, risks and recession may require different policies responses. European countries have used different combinations of monetary, fiscal and direct $\mathrm{t}$ support instruments. The balance between national policies and international coordination is contradictory. International economic risks management should be based on time-fashioned targets and instruments. Short-term economic policies should be focused on the economies recoveries. Medium-term policies should include structural and sustainability instruments, Long-term policies should be focused on drivers of innovations, education, research and inclusive development.

\section{References:}

1. Blanchard O. Rethinking Macroeconomic Policy/ IMF staff discussion note. SPN 10/03 International Monetary Fund. Washington. 2020. 21 p. Available at: https://www.imf.org/en/Publications

2. Eichenbaum M., Rebelo S.,Trabandt M. The Macroeconomics of Epidemics, NBER Working Paper 26882, 2020. 54 p. Available at: www.nber.org/papers/26882

3. European Commission. European Economic Forecast. Summer 2020. European Commission. Brussels. 2020. 52 p. Available at: https://ec europa.eu/info/ publications/economic-and-financial-affairs_en

4. European Commission. European Economic Forecast. Autumn 2020. European Commission. Brussels.2020 224 p. Available at: https://ec.europa.eu /info/sites/info/files/ economy-finance/ip136_en_2.pdf

5. Eurostat. EU's electricity consumption lover in April 2020. Available at: https://ec.europa.eu/eurostat/en/web/products-eurostat-news/-/DDN-20200714-2 
6. Eurostat. Data GDP. 20206 p. Available at: https://ec.europa.eu/eurostat/ documents/2995521/11156775/2-31072020-BP-EN.pdf/cbe7522c-ebfa-ef08-be60-b1c9d1 bd385b

7. .IATA. COVID-19 fourth impact assessment. IATA Geneva. 2020. 8 p. Available at: https://www.iata.org/en/iata-repository/publications/economic-reports/covid fourth-impactassessment/

8. ILO Monitor: COVID-19 and the world of work. 5 ed. International Labor Organization. Geneva. 2020. 11 p. Available at: https://www.ilo.org/wcmsp5/groups/ public/dgreports/dcomm/documents/briefingnote/wcms_740877.pdf

9. Lettan M., Ludvigson S. Shocks and Crashes. NBER Working Paper 16996.73 p. 2011. Available at: www.nber.org/papers/16996

10. Jordà O., Singh S., Taylor A. The longer run economic consequences of pandemics. 2020. 8 p. Available at: www.vox.org

11. Kose A., Sugavara N. Understanding the depth of the 2020 global recession in 5 charts. World Bank. 2020. 10 p. Available at: https://blogs.worldbank.org/opendata/ understanding-depth-2020-global-recession

12. Natsionalny bank Ukrainy. Macroeconomichnyi i monetarnyi ogliad (Ukrainian) (National bank of Ukraine. Macroeconomic and monetary review). Kyiv, 2020, 15 p. Available at: www.bank.gov.ua

13. Reed E.Economic Shocks Definition and Examples. 2020. 8 p. Available at: https://finance.yahoo.com/news/economic-shocks-definition-examples-221454349.html

14. International Monetary Fund. June 2020 World Economic Outlook update. 21 p. Available at: https://www.imf.org/en/Publications/WEO/Issues/2020/06/24/WEOUpdate June2020

15. International Monetary Fund. World Economic Outlook. October 2020. 204 p. Available at: https://www.imf.org/en/Publications/WEO/Issues/2020/09/30/worldeconomic-outlook-october-2020 